\title{
Analysis on energy and economic sustainability from the perspective of dynamic definition of economic security
}

\author{
Vladimir Vorozhikhin \\ Financial University under the Government of the Russian \\ Federation, Institute for Economic Policy and Economic \\ Security Problems \\ Moscow, Russia \\ vorozhikhin@mail.ru
}

\author{
Vladimir Starovojtov \\ Financial University under the Government of the Russian \\ Federation, Institute for Economic Policy and Economic \\ Security Problems \\ Moscow, Russia \\ VStarovojtov@fa.ru
}

\author{
Igor Tyutyunnik \\ Financial University under the Government of the Russian Federation, \\ Institute of Industrial Policy and Institutional Development, \\ Moscow, Russia \\ tytynnik.igor@rambler.ru
}

\begin{abstract}
The article is about the use of the modern definition of economic security, formulated as a result and a process of sustainable development to achieve a better future of the country. The article describes the approach search results for improvement of economic security based on process dynamics. The schemes of achievement of economic sustainability are presented based on the application of dynamic definition of economic security. Dynamic definition of security builds the concept and approach. Within this framework the article aims to identify and analyze the security evaluation, that requires a toolkit support.
\end{abstract}

Keywords-economic security, analysis and compellation of definitions, sustainable future, risk assessment and management, economic security strategy, system of global security, complex active systems, innovational approaches

\section{INTRODUCTION}

Rapid transformation of the world order, external pressure in the most diverse forms, as well as innovative development of the country, violate the established business operations of economic agents, regions and the country as a whole. The complexity and short-termism of change processes requires a transition from static approaches to the dynamic definition of security as a process and the result of achieving a goal of sustainablee future for the country. [1]. The definition should fundamentally eliminate "blind zones", where threats can be formed, shape clear and unambiguous schemes and a methodology for identifying their future images, despite the existence of fundamentally unclear processes for a number of positions. The new approaches should be applied to create new tools that should allow Russia to achieve global competitiveness and economic security.
The purpose of the research is to find approaches to improve economic security, considering the dynamics of processes and approbation of the approach for analyzing the energy and economic stability of the region.

\section{MATERIALS AND METHODS (MODEL)}

This article analyzes and summarizes regulatory instruments in the area of economic security of Russia. The research describes the dynamic definition of economic security and the schematics of the process how to achieve security. The issue of energy and economic sustainability of the country and the region is addressed based on the approaches of the "energy trilemma" and schemes of the regional simulation model of RIM (RSM). The approach has been developed, and an example is provided with an application of the dynamic definition of economic security for the formation of the model of energy and economic stability for the region.

\section{RESULTS AND DISCUSSION}

\section{A. Reflection of economic security in regulatory instruments in Russia}

The issues of economic security are directly and indirectly reflected in a number of Russia's strategic papers.

The Constitution of the Russian Federation [2] refers six times to the state security: the prohibition of activities aimed at undermining the state security (Article 13, paragraph 5); the possibility of limitation of the rights and freedoms of a person and citizen for the state security (Article 55, paragraph 3), the 
conditions for these restrictions - the introduction of a state of emergency and the indication of the terms of their action (Article 56, paragraph 1); security as well as defense is attributed to the jurisdiction of the Russian Federation (Article 71, paragraph $\mathrm{m})$ ); the public safety of the Federation is included in the jurisdiction of the Russian Federation and the subjects of the Russian Federation (Article 72, paragraph 1, subparagraph b), ensuring environmental safety (Article 72, paragraph 1, pp. e)); the ability to restrict the movement of goods and services to ensure security (Article 74 para. 2). The text mentions two types of threats - for life and health of people and aggression. In the Russia's National Security Strategy [3] stipulated that , National security includes the country's defense and all types of security envisioned by the Russian Federation Constitution and Russian Federation legislation -- primarily state, public, informational, environmental, economic, transportation, and energy security and individual security". (paragraph 6). In the strategy, international security (p. 29), military (p.33), security in the area of protecting the population and territory from natural and manmade disasters, and in the area of fire safety (p. 49), food (p.54), security in the area of science, technology and education (pp.67-69). The development of health care and the strengthening of the health of the Russian Federation's population (paragraph 71), national security in the sphere of culture (paragraph. 76), environmental security (p. 83).

Out of 10 indicators of assessing the state of national security, 7 are directly related to economic security.

In the Economic Security Strategy [4], "economic security" is defined e state of protection of the national economy against external and internal threats, which ensures the economic sovereignty of the country, the unity of its economic space and conditions for realization of strategic national priorities of the Russian Federation (article 7, paragraph 1).

In the Economic Security Strategy, particularly securityobjects are not disclosed. Areas are assigned indirectly (p. 27) through "indicators of the state of economic security" totaling 40. The methodology for the formation of indicators, the need and the conditions for their change are not disclosed. The execution of the Strategy is implemented in two stages (I - until 2019, II-to 2030) and should (p. 38) "ensure the economic sovereignty of the Russian Federation and the stability of the national economy to external and internal challenges and threats, as well as the strengthening of socio-political stability, dynamic social and economic development, raising of the level and improving of the quality of life of the population."

Critics of the Economic Security Strategy point out its weak points [5]:

- delay in implementation until 2019;

- set-up in the lack of the country's development priorities;

- parameters of economic security are provided as a list without indication of the goals to be achieved;
- it is not specified how the result of the monitoring will be interpreted further;

- there are no sanctions for failing to implement the strategy;

- discrepancy between the challenges, threats, tasks and indicators;

- there is no indication of a change in the economic model that reflects the exhaustion of the possible economic growth within the raw-material model;

- continue to rely upon foreign investment in during sanctions;

- the government continue to consider poverty status to those whose income is below the subsistence minimum, whereas the subsistence minimum does not cover even the minimum of needs.

The abovementioned problems and imperfections of ideas force the experts to search for new ways to improve approaches to security.

\section{B. The relevance of the proposed definition of economic security and the scheme of the process of security achievement}

In practice, understanding what to regard as a threat and how to deal with it is not solid. Between the emergence of a threat and the formation of a set of measures to combat it, there is always an intermediate link - the economic concept, within which the emerging problem is comprehend and disclose [6].

A feature of the current stage of development has been the expansion of significant areas of economic security, including increased interest in ensuring regional economic security. Previously, the object of the study for economic security at the macro level was exclusively the state. However, divergence processes are increasing as new sophisticated technologies are implemented, and the latest achievements of scientific and technological progress become available to people, living in fewer and smaller number of regions. That have led to an increase in social and territorial differentiation of the development of society and, as a result, to the urgency of the problem of regional economic security [7].

The core of economic security is the transition from the current state of the economy and national security to a favorable future.

An analysis of existing definitions of economic security in research, their problems and the synthesis of a new definition are described in [1]. As a definition of economic security, the following is proposed:

Economic security is the realization of economic conditions for the achievement of a favorable future for the state, markets and business companies, for the scientific and expert community, civil society institutions and every citizen, regardless of possible changes in the external and internal situation within the inclusive, effective and sustainable 
process of achieving it, ensuring diagnostics and resolution of development problems, identification and use of all development opportunities, current and strategic competitiveness of the country development.

It is important to describe correctly the scope for achieving economic security (see Figure 1). The current states are shown in the left part of the figure, the future states are shown on the right. The area of economy is marked by dashed line and the sphere of national security and is solid on the left and the dash-dotted line on the right. In the figure, below and in the central part, the national security sectors (NS) are represented (in the current one they are covered by a thin solid line in the left part of the figure, in the future - a dashed line, on the right). In the sectors of the NS that are included in the sphere of economic security, the economy of these sectors is show as the ovals, which is part of the economy (covered by a thick, dashed drawn line). The top part of the figure shows schematically the process of economic development and its transition from the current state to the future, the lower part of the figure shows the change in the state of national security current-future (wide arrows). The sphere of economic security covers its core, the elements of the current and future economy and national security, as well as the ongoing processes of transition to the future and the final state of the sectors of the economy of the NS sectors (2-dot bar-dotted line).

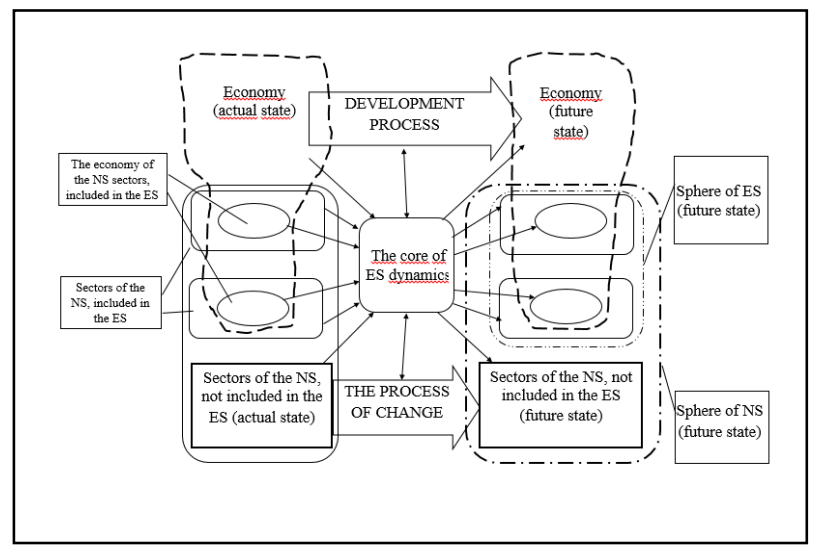

Fig. 1. Scheme of representation of the sphere of economic security, defined as ensuring the favorable future of the country and the process of its achievement.

The core of economic security determines the transition from the current state of the economy and national security to the desired (shown in the center of the figure). The core is influence by the current state of the economy and the current state of the components of national security. The core interacts with the processes and determines the future states of the national security sectors (NS) - shown on the right side of the figure, also included in the sphere of economic security (covered by a dashed line), ovals represent the economy of these sectors.

Decomposition is realized from the conditions of preserving the integrity of the review of the economy, national and economic security, while assessing the model's errors (losses), risks and data risks.

Decomposition is necessary to identify specific risks and management methods that differ significantly for different spheres of economic and national security: the risk models and their management within these areas, as a rule, will be significantly different. When decomposing, it is necessary to represent possible errors and information losses associated with the way it is implementing. The depth of the decomposition is determined from the conditions for the absence of new significant effects, while not only the magnitude of the loss of influence from the inaccurate setting of the model is estimating, but also the rate of increase of the effect.

At the same time, some economic issues in the area of national security sectors do not determine the situation in economic security, for example, due to low importance or resolution by other methods. The processes of transformation of the economic system and the national security system are partially determined in the strategic planning process, partially are changed within the framework of the situation change, and it is also changed within the framework of the operative reaction of the authorities. Thus, in determining the economic security, it is necessary to proceed from the concept of economic governance, rather than strategic planning, which sets the invariable image of the future.

The processes of local influence and interaction are showing by thin arrows. When integrating the systems "economy (future state)" (covered by the dashed line on the right) and "national security (future state)" (covered by a dotdash line on the right), it is necessary to take into account synergistic processes.

\section{Energy sustainability of the economy and the problems of its definition within the framework of the "energy trilemma" approaches}

The concept of sustainable development is associated with the improvement of theories of economic growth, which take into account the social and environmental aspects of economic growth [8].

Sustainable development of the country is interdependent by sustainable energy development. There it is important to ensure the harmonization of reliability, environmental friendliness and availability of energy supply for modern energy (power engineering). In the framework of modern ideas, a joint solution of these problems is considering by specialists within the framework of the resolution of the "energy trilemma" [9].

The energy trilemma is an attempt to diagnose and select a model for the development of the energy system based on three most important alternative parameters: energy security; availability of energy for the population; ecological compatibility of power supply.

The methodology of the "energy trilemma" was developing by the World Energy Council (WEC), which unites the countries of the world using energy, 3000 organizations, 90 national committees, carries out independent 
expertise and development of global innovative solutions in the field of energy management.

The change in the list of indicators is based on the principles used in the formation of the Energy Trilemma Index [10]: reliability; context sensitivity; relevance; concentration (focus): prevalence (covering a significant volume of the study area). The modern methodology of the Trilemma-2016 Index has a wider coverage to provide a more adequate representation of the energy sector; gives an idea of the prospective energy efficiency by collecting data of the sustainability of the country's energy system and seeks to reduce the potential impact of richer countries. The main measurements of stability are present in Table I.

TABLE I. ОСНОВНЫЕ ИЗМЕРЕНИЯ УСТОЙЧИВОСТИ РАЗВИТИЯ ЭНЕРГЕТИКИ И КАТЕГОРИИ ИНДИКАТОРОВ [9]

\begin{tabular}{|c|c|c|c|}
\hline Dimension & $\begin{array}{l}\text { Weight, } \\
\%\end{array}$ & Indicator category & $\begin{array}{c}\text { Weight, } \\
\%\end{array}$ \\
\hline \multirow{2}{*}{$\begin{array}{l}\text { Energy } \\
\text { security }\end{array}$} & \multirow{2}{*}{30} & $\begin{array}{l}\text { Security of supply and energy } \\
\text { delivery }\end{array}$ & 15 \\
\hline & & Resilience & 15 \\
\hline \multirow{3}{*}{ Energy equity } & \multirow{3}{*}{30} & Access & 10 \\
\hline & & Quality of Supply & 10 \\
\hline & & Economic and competitive & 10 \\
\hline \multirow{3}{*}{$\begin{array}{l}\text { Environmental } \\
\text { sustainability }\end{array}$} & \multirow{3}{*}{30} & Energy efficiency & 10 \\
\hline & & Greenhouse gas emissions & 10 \\
\hline & & $\mathrm{CO} 2$ emissions & 10 \\
\hline \multirow{5}{*}{$\begin{array}{l}\text { Country } \\
\text { context }\end{array}$} & \multirow{5}{*}{10} & $\begin{array}{l}\text { Consistency and predictability } \\
\text { of policies }\end{array}$ & 2 \\
\hline & & $\begin{array}{l}\text { Stability of the regulatory } \\
\text { environment }\end{array}$ & 2 \\
\hline & & $\begin{array}{l}\text { Support for R \& D (research, } \\
\text { development and } \\
\text { demonstration) and innovation }\end{array}$ & 2 \\
\hline & & Investment Opportunities & 2 \\
\hline & & $\begin{array}{l}\text { Exposure to air, land and water } \\
\text { pollution }\end{array}$ & 2 \\
\hline
\end{tabular}

For each of the four areas (energy security, energy equity, environmental sustainability and the context of the country), detailed categories of indicators have been developed that cover key aspects of the sustainability of national energy systems. For example, when assessing energy security, security of supply and energy supply and the viability of the energy infrastructure are taken into account. The categories of the indicator have been to make up of a corresponding set of indicators. A total number of 35 indicators was been developed, which composed of 71 data groups.

A feature of the energy model is its multifactorial and complexity, spatial, fuel, technological and regime diversity of generation, transmission, distribution and consumption of energy. Energy accounts for about $35 \%$ of the Russian budget, determines the filling of the revenue part by about $50 \%$, and the basis for the formation is of a life support system in the climatic conditions of Russia, too. Power engineering also constitutes a significant share of industry.
Modern models also describe the mutual influence of energy and economy, which carries out both directly and indirectly through the social sphere and ecology and thus interact with both the economy and energy, and among themselves.

Schemes of influence have been developed with varying degrees of detail. One of the working schemes of the regional simulation model (hereinafter $\mathrm{PИM}=\mathrm{RSM}$ ) [11] is presented in Figure 2.

\section{Application of the definition of economic security for the model of energy-economic sustainability}

An approach, which is similar to that used in the definition of economic security, can be used to develop a model of the dynamics parameters of the energy sustainability of the economy or the mutual influence of economic and energy security.

The actual state of energy can be determining by the system of basic indicators of the Energy Strategy-2035, the list of risks and threats based on the Doctrine of Energy Security and a review of domestic and foreign dissertational research in the field of economic and energy security. Indicators of the future state of the economy and energy can be adjusting to their significance changes in the future.

The design of the multi-model complex is initially conducting as a human-computer system.

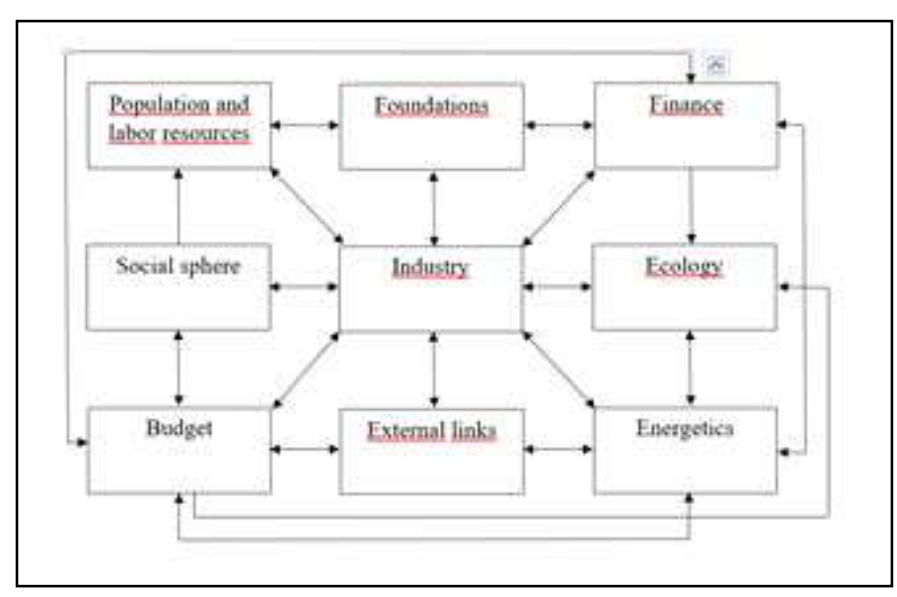

Fig. 2. Structure and interrelations of the elements of the PИM model

The created tool is building in the multi-model complex, which has in the long term a developed territorial system, including:

- a model of the world economy with details that are not inferior to modern foreign models (IHS [12]:> 95\% of the global economy,> 75 (up to 238) countries;

- a model of the Russian economy with details to the level of municipalities, including large, medium and small enterprises, information on the economic state of households and the quality of life of each person;

- the world energy model, including experience in creating the energy part of the IHS model, the ETIP- 
SNET model set in the EU related to the research team RT5 (the general model of the CGM network, METIS v1.1 [13, 14], with hourly simulation and accounting 10-year scenarios, 6 modules - power systems, including a reserve model, a gas system module, an electricity market with models for daily and balancing markets, the Stochasticity module (generation of a time series of data for the system - generation of renewable energy sources (RES) and the needs of 28 countries, a maximum of 50 weather forecasts, forecast of renewable energy generation and needs of 28 countries, volatility, reservation of calibration), price proposal (4 scenarios for actual variable electricity production costs, strategic, oligopoly, fixed costs);

- model of power engineering in Russia;

- models of regional energy complexes; and

- models of power complexes of municipalities.

The source of threats are the administrative institutions that lagging behind in development, imposing on society their own representations, formed on the myths of the past, , living at the expense of the neighbor, defending personal interests under the guise of caring for the public.

Figure 3 shows the relationship schema that is taking into account when modeling and making decisions in the logic of the scheme in Figure 1. It takes into account the actual and future states of energy and economy that link from social sphere and ecology, the actual state of which influences the formation of the core of the process of changing the energy and economic stability (EES). This core determines, through the impact on the future conditions of the social and environmental spheres, the conditions for transition to future energy and economic conditions. Processes are also interdependent. The core of energy and economic sustainability (EES) is constructing from the perspective of a vision of a favorable future for the economy, social sphere and energy based on the methodology of the "energy trilemma" and the decomposition of the PИМ (RSM) model. Formation of the core of the power grid is being implemented, taking into account the Strategy of Economic Security and the Doctrine of Energy Security. Such a partner for Russian has emerged on its own: The United States assumed the role of the developer of the ideal of the future Russia and had been its implementation.

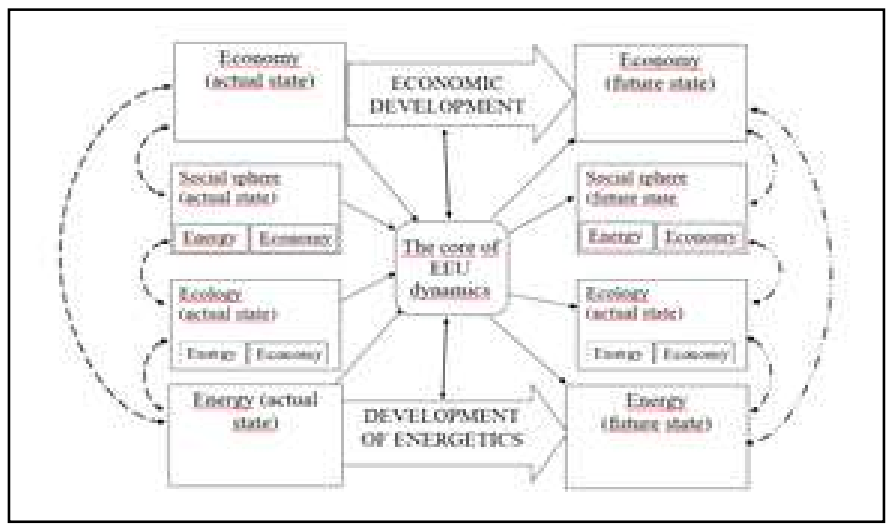

Fig. 3. Scheme of dynamics of the process of energy-economic sustainability taking into account energy-socio-eco-economic interaction

Hence, the requirement for an instrument for ensuring economic security is the ability to preserve its sovereignty in all areas of interaction, including the managerial one.Since the information flood without the information processing system not only takes away the most important knowledge, but it also creates the information noise that distorts the area of knowledge, any work without a special tool forms the simulation mode of the entire system of economic security. For example, it is required to develop a specialized geoinformation system for the energy security sector [15, p. 24].

The influence of the external environment in the model is viewed as a relation of two subject: it provides for the possibility of targeted impacts, the effects of transformations in other areas of the global environment and unpredictable impacts (jokers and chaotic impacts). A search for some scenarios of impact on critical connections and agents in a state close to critical is being conducted. The scenarios consider the possibilities of support (initiation) and the formation of barriers. It is necessary to implement a complex multi-model system to governance the country, its scientific, technological and socio-economic development, ensuring competitiveness and security oriented, intelligent interactive management system, originally designed and implemented as a human-computer system. The short descriptions - the images - of such a system were published in 2009 and 2012. [16]

\section{CONCLUSION}

\section{A. The definition presets the model for considering security and sustainability}

The definition of security forms a system of approaches within which its research and evaluation are conducted. Static mechanic approaches at the level of global and country management of risks and threats, the definition of security as a current state are inapplicable in principle. The loss of a number of dimensions of complex space leads to erroneous decisions, to the necessity of forced actions instead of regulatory ones, to loss of opportunities and development potential, competitiveness and creation of internal problems that can be solved outside the legal, moral or ethical fields. In other words, the main problems in the field of management are creating by imperfections of the model of the control system 
itself. To avoid problems associated with the security model, a transition from the concept of strategic planning to the concept of strategic management is necessary.

\section{B. It is necessary to conduct comparative studies of traditional and dynamic approaches}

Number of studies must be conducted to determine the appropriateness of the practical use of dynamic approaches energy-economic steadiness of Russian regions.

\section{The need of instrumentally support the management of safety and stability}

For competitive security activities, a tool is needed that is suitable for investigating the dynamic interaction of complex active systems with counter research programs that have competing and partner interests. Elimination of imperfections is impossible without the creation of such a complex instrument. Without tools, we risk losing sight of the top governance floor and Russia's economic security in the world of the future, having formed only the technological floor of the digital economy and kindly providing it for a foreign system of global governance. The starting point is the dynamic definition of economic security - the process and result of achieving a favorable future for the country.

If the management structures are not able to solve such a problem, they fundamentally change the ways and the very nature of the activity, putting pressure on everything that does not fit into the template, which somebody created in the past, but use it as the ideal of modernity. Repressive structures are the principal enemy of innovative solutions that are so necessary for Russia to narrow the development gap in relation to a group of developed countries and realize the potential and development opportunities that can create a favorable future, so much desired by everyone.

\section{Acknowledgment}

This article was written in preparation for carrying out studies on threats and risks of socio-economic systems by the Financial University on behalf of the Government of the Russian Federation and the Ministry of Economics of Russia.

\section{References}

[1] Vorozhikhin V.V. On the actualization of the definition of economic security, Business Security, 2017, No. 6. ss. 3-9. [Ob aktualizatsii opredeleniya ekonomicheskoy bezopasnosti] (in Russian)

[2] The Constitution of the Russian Federation (adopted December 12, 1993), ATP ConsultantPlus [Konstitutsiya RF (prinyata 12 dekabrya 1993 goda)]. (in Russian)
[3] The National Security Strategy of the Russian Federation (approved by the Decree of the President of the Russian Federation No. 683 of December 31, 2015), ATP ConsultantPlus [Strategiya natsional'noy bezopasnosti Rossiyskoy Federatsii (utv. Ukazom Prezidenta Rossiyskoy Federatsii ot 31 dekabrya 2015 g. N 683)]. (in Russian)

[4] The Strategy of Economic Security of the Russian Federation for the Period to 2030 (approved by the Decree of the President of the Russian Federation of May 13, 2017 No. 208), ATP ConsultantPlus [Strategiya ekonomicheskoy bezopasnosti Rossiyskoy Federatsii na period do 2030 goda (utv. Ukazom Prezidenta Rossiyskoy Federatsii ot 13 maya 2017 g. № 208)] (in Russian)

[5] Kravchenko L.I. Strategy of economic security of Russia until 2030 as a new pre-election maneuver - [Electronic resource] - URL: http://rusrand.ru/analytics/strategiya-ekesticheskoy-bezopasnosti-rossiido-2030-goda-kak-novyy-predvybornyy-manevr (date of circulation on 26.06.2017) [Strategiya ekonomicheskoy bezopasnosti Rossii do 2030 goda kak novyy predvybornyy manevr] (in Russian)

[6] Levkina S.V. Toolkit for managing the level of economic security of the country - dissertation for the degree of Cand.Sc. in Science - SPb .: FGBOU VO "Saint Petersburg State Economic University", 201 p. [Instrumentariy upravleniya urovnem ekonomicheskoy bezopasnosti strany - dissertatsiya na soiskaniye uchenoy stepeni kand.ekon.nauk] (in Russian)

[7] Arbuzov SG Peculiarities of methodological and methodological support of economic security of the state at the present stage - dissertation for the degree of Doctor of Science St. Petersburg: FBBUN "St. Petersburg Scientific Center of the Russian Academy of Sciences", 2017 - 360 p. [Osobennosti metodologicheskogo i metodicheskogo obespecheniya ekonomicheskoy bezopasnosti gosudarstva na sovremennom etape dissertatsiya na soiskaniye uchenoy stepeni dokt.ekon.nauk]

[8] Jackson T. Prosperity Without Growth, Sustainable Development Commission, March 2009, 136 p.

[9] N.H. Afgan, MGS Carvalho, N.Hovanov Modeling of energy system sustainability index, THERMAL SCIENCE: Vol. 9 (2005), No. 2, pp. 3-16

[10] World Energy Trilemma Index 2016, WEC, 147 p.

[11] Methods and models for the development of regional energy programs / Saneev BG, Sokolov AD, Agafonov GV and others - Novosibirsk: Nauka, 2003. 140 p. - p.80 [Metody i modeli razrabotki regional'nykh energeticheskikh programm] (in Russian)

[12] Global Link Model - URL: https://www.ihs.com/products/global-linkeconomic-model-and-scenarios.html (accessed date 22.11.2017)

[13] METIS Studies, Study S04 Generation and System Adequacy Analysis, January 2016, 82 p.

[14] METIS Technical Note T5: METIS software introduction and architecture, May 2017, 16 p.

[15] Pashigorov V.S. Strategy of energy development in the policy of ensuring economic security of Russia - dissertation for the degree of Cand.Sci. - St. Petersburg: "St. Petersburg State Economic University", 2015 - 162 p. [Strategiya razvitiya energetiki v politike obespecheniya ekonomicheskoy bezopasnosti Rossii - dissertatsiya na soiskaniye uchenoy stepeni kand.ekon.nauk] (in Russian)

[16] Vorozhikhin V.V. Hyperprognostic system (GPS) - a tool for interactive intellectual control system of the country (IISUS) - [Electronic resource] - URL: http://innclub.info/wp-content/uploads/2012/04/vorozhin.doc (accessed date 26.06. 2017) [Giperprognosticheskaya sistema (GPS) instrument dlya interaktivnoy intellektual'noy sistemy upravleniya stranoy (IISUS)] (in Russian) 